\title{
22. AMINO ACIDS IN SEDIMENTS FROM LEG 68 SITE $502^{1}$
}

\author{
Keith A. Kvenvolden and David J. Blunt, U.S. Geological Survey, Menlo Park, California
}

\section{INTRODUCTION}

Interest in amino acids in sediments began with the work of Erdman et al. (1956), which showed that these organic compounds are found in recent as well as ancient marine sedimentary deposits. This research, along with Abelson's (1954) investigations on fossils, firmly established the general ubiquity of amino acids in ocean sediments and led to numerous follow-up studies (for reviews, see Abelson (1963), Hare (1969), and Kvenvolden [1975]). Because of the difficulties in sampling marine sediments, the first work was limited to samples taken at depths of less than about 5 meters below the ocean bottom. In this depth range, for example, samples of amino acids were described from reducing sediments from Santa Barbara Basin (Degens et al., 1961) and from oxidizing sediments from the San Diego Trough (Degens et al., 1963). With advancing technology, deeper samples became available, and amino acids were found in sediments from Experimental Mohole (Rittenburg et al., 1963). With the advent of the Deep Sea Drilling Project (DSDP) in 1968, core samples of sediment from all of the world's oceans except the Arctic have become available for organic geochemical studies. Wehmiller and Hare (1972) first discussed the occurrences of amino acids in sediments from Legs 5, 6, 7, and 9, and Aizenshtat et al. (1973) considered the amino acids in a sediment core from Leg 4.

This early work on cores recovered by deep ocean drilling stressed not only the content but also the stereochemistry of the amino acids. The importance to geochemistry of the stereochemical properties of amino acids was first recognized by Hare and Mitterer (1967) and Hare and Abelson (1968) through considerations of the diastereomers L-isoleucine and D-alloisoleucine. Lisoleucine from protein undergoes an interconversion (epimerization) to yield D-alloisleucine. The extent of epimerization is used within certain limitations to estimate the age of the sediment (Bada et al., 1970; Wehmiller and Hare, 1971; Bada and Schroeder, 1972). Studies utilizing DSDP samples have considered the epimerization (usually called racemization) of isoleucine in sediment samples from Leg 15 (Hare, 1973; Bada and Man, 1973), Leg 37 (Bada et al., 1977), Leg 42A (Bada et al., 1978a), and Leg 42B (Mopper et al., 1978). In addition to measuring the epimerization of isoleucine, Aizenshtat et al. (1973) determined the extent of racemization of six amino acids in a sediment core from Leg 4 ,

\footnotetext{
${ }^{1}$ Prell, W. L., Gardner, J. V., et al., Init. Repts. DSDP, 68: Washington (U.S. Govt. Printing Office).
}

and Bada and Man (1980) discuss the racemization of alanine and aspartic acid in sediments from Leg 15 .

In this chapter, we will report on the amino acids in the total acid hydrolysate of eight sediment samples from Leg 68 Site 502. This site was located on a topographic high at a depth of 3051 meters in the Colombian Basin of the western Caribbean Sea. Four holes were cored at the site by means of the hydraulic piston corer to a maximum sediment depth of 218 meters. The composite section is a virtually continuous, undisturbed sediment record covering almost 8 million years from the Holocene to late Miocene. Age estimates for the section are based on excellent magnetostratigraphic and biostratigraphic records. Four lithostratigraphic units (A, $B, C$, and D) were recognized, based on differences in color and content of clay, ash, foraminifers, and siliceous microfossils (Prell, Gardner, et al., 1980): A, yellowish brown to light brownish gray foraminiferbearing ( $>10 \%$ ) nannofossil marl; B, gray to olive gray foraminifer-bearing nannofossil marl with occasional ash beds; $\mathrm{C}$, light gray to dark greenish gray calcareous clay and foraminifer-bearing $(<10 \%)$ nannofossil marl; $\mathrm{D}$, pale green to grayish green calcareous, ash-bearing clay with siliceous microfossils. The calcium carbonate content of these sediments increases from about 27 to about $49 \%$ from late Miocene to middle Pliocene ( 3.6 Ma) and remains uniform at about 48 to $50 \%$ from that time throughout the Quaternary. The eight sediment samples for amino acid analyses came from the third (502B) and fourth (502C) holes at Site 502. Samples ranged in sub-bottom depth from 4.3 to 225 meters spanning time from 0.3 to $7.7 \mathrm{Ma}$ (Fig. 1).

\section{METHODS}

Eight core samples, each $30 \mathrm{~cm}$ long, were collected at the time of drilling. These were immediately frozen and became part of the large inventory of frozen samples maintained by DSDP at Scripps Institution of Oceanography. Each of the eight core samples was sawed longitudinally into quarters, and a $15-\mathrm{cm}$ long quarter-core was taken for amino acid analyses.

The procedures used to extract amino acids from the total sediment follow the procedures of Bada and Man (1973). Briefly, a 3 to 4 $\mathrm{g}$ portion of the 15-cm quarter-core was hydrolyzed in $6 \mathrm{~N} \mathrm{HCl}$ for 24 hr. at $110^{\circ} \mathrm{C}$ in a sealed tube under nitrogen. The resulting hydrolysate was separated from the insoluble residue by centrifugation. Analyses of this amino acid extract followed slightly modified procedures given by Kvenvolden et al. (1979). The solution containing amino acids was evaporated to dryness and taken up in $0.1 \mathrm{~N} \mathrm{HCl}$. Norleucine was added as an internal standard. This mixture, adjusted to $\sim \mathrm{pH} 1$, was desalted on $60 \mathrm{ml}$ of Dowex ${ }^{2} \mathrm{AG} 50 \mathrm{~W}-\mathrm{X} 8\left(\mathrm{H}^{+}\right)$cation exchange resin. Amino acids were eluted with $1.5 \mathrm{~N} \mathrm{NH}_{4} \mathrm{OH}$, and the eluate was evaporated to dryness, taken up in distilled water, and sonicated to insure complete mixing. The resulting solution was divided into equal parts, and each was evaporated to dryness. One of the dried portions was dissolved in $1 \mathrm{ml}$ of $\mathrm{pH} 2.2$ sodium citrate buffer for determination of concentrations by means of an automated amino acid ana- 


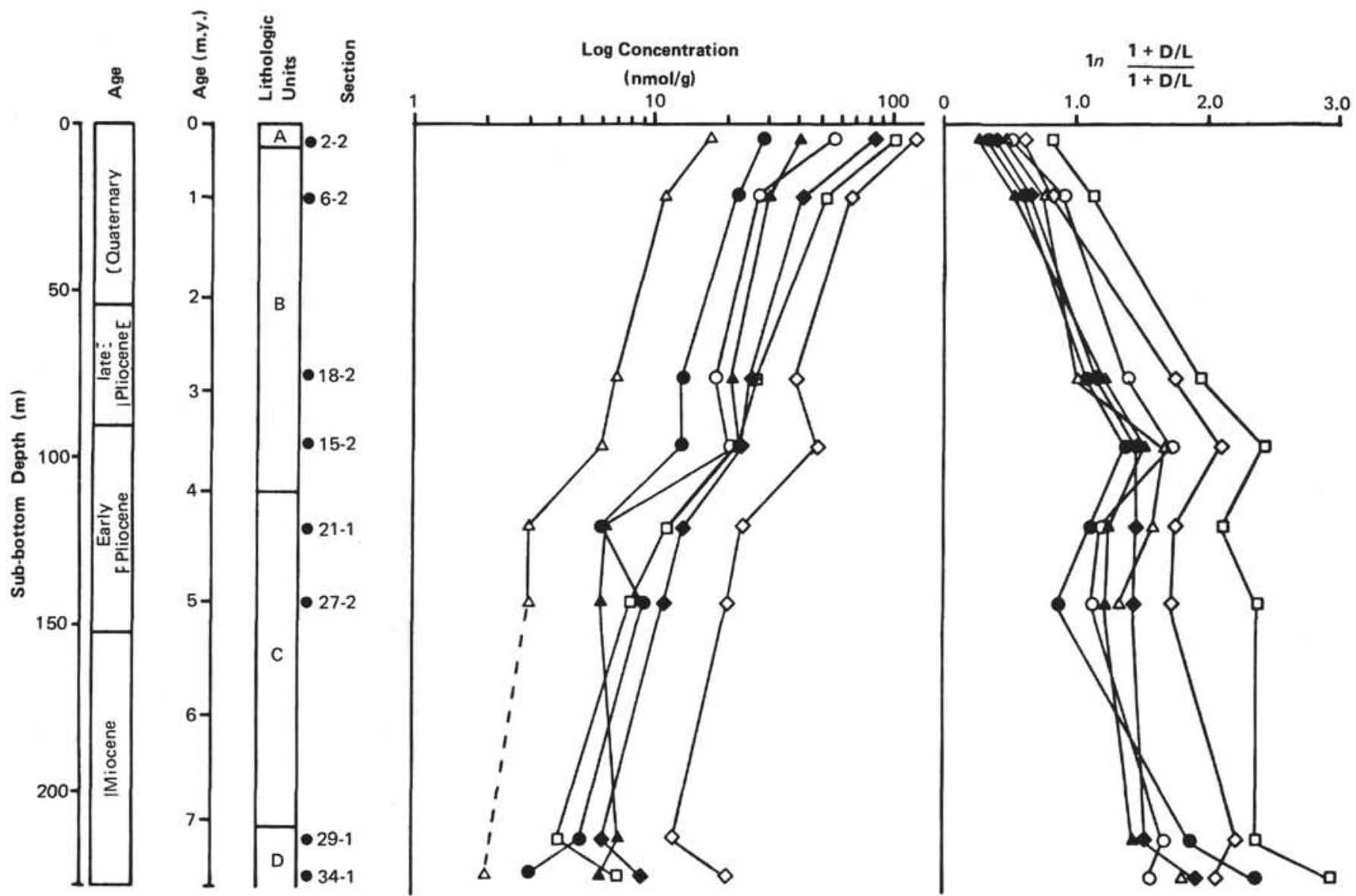

Figure 1. Diagram showing concentrations and extents of racemization of amino acids in eight sediment samples from Site 502, Leg 68. Samples are located in appropriate stratigraphic and geochronologic order. (Concentrations of amino acids in $\mathrm{nmol} / \mathrm{g}$ are expressed as logarithms ${ }_{10}$. The extents of racemization (D/L ratios) are expressed as the left-hand term of equation 1 in the form of logarithms. Identification symbols are: $\square$ aspartic acid, $\diamond$ alanine, $\bigcirc$ proline, $\triangle$ phenylalanine, $\bullet$ leucine, $\bullet$ glutamic acid, $\Delta$ valine.)

lyzer. The other dried portion was acidified with $0.1 \mathrm{~N} \mathrm{HCl}$ and evaporated in preparation for derivatization and quantitation of enantiomeric $(D / L)$ ratios of amino acids by gas chromatography.

Concentrations of amino acids were determined on a Beckman ${ }^{2}$ Model $119 \mathrm{CL}$ amino acid analyzer. One hundred $\mu \mathrm{l}$ of the $1-\mathrm{ml}$ portion of extract in sodium citrate buffer were analyzed, and the concentrations of individual amino acids were quantified against the norleucine internal standard by integration of the resulting chromatograms (Fig. 2) using a Beckman ${ }^{2}$ Model 126 data system. Concentrations are reported (Table 1) in nanomoles of individual amino acid per gram of sediment $(\mathrm{nmol} / \mathrm{g})$.

Preparation of amino acid derivatives for gas chromatography followed procedures described by Kvenvolden et al. (1972) with the exceptions that esterification was carried out in an open rather than closed system and that pentafluoropropionic anhydride (PFPA) was used for derivatization rather than trifluoracetic anhydride. The resulting $\mathrm{N}$-PFP-(+)2-butyl esters were dissolved in dichloromethane and analyzed by flame ionization gas chromatography (Varian ${ }^{2} 3700$ and Perkin-Elmer ${ }^{2}$ 900) on stainless steel capillary columns $(60 \mathrm{~m} \times$ $0.08 \mathrm{~mm}$ coated with UCON $75-\mathrm{H}-90,000$ and $60 \mathrm{~m} \times 0.12 \mathrm{~mm}$ coated with Carbowax $20 \mathrm{M})$. Enantiomeric $(D / L)$ ratios of amino acids were obtained by measuring peak heights on gas chromatograms (Fig. 3), and these ratios are reported in Table 1.

\section{RESULTS AND DISCUSSION}

The eight sediment samples used for this work were collected by means of the hydraulic piston corer. These

\footnotetext{
2 The use of trade names is for descriptive purposes only and does not constitute an endorsement by the U.S. Geological Survey.
}

samples provided a unique opportunity to follow changes with time of amino acid composition and extent of racemization in a continuous, almost undisturbed sedimentary record. We determined the concentrations of sixteen amino acids (Table 1) and measured the extent of racemization of seven of these compounds (Table 1) in a stratigraphic sequence of eight increasingly older samples. The amino acids were recovered by acid hydrolysis of the total sediment. They represent a composite mixture of both free and bound amino acids. No attempt was made to fractionate the amino acids further. Identification of individual amino acids was based on retention times of ninhydrin-positive compounds separated during ion-exchange chromatography. In addition to fourteen protein amino acids, two nonprotein amino acids, $\gamma$-aminobutyric acid $(\gamma$-ABA) and $\beta$-alanine $(\beta$ ALA), were identified (Table 1).

In general, the concentrations of the total as well as individual amino acids decrease with depth and time. From the youngest sample back in time to about 3.6 m.y. ( $100 \mathrm{~m}$ sub-bottom), the content of total amino acids decreases from about 1000 to about $350 \mathrm{nmol} / \mathrm{g}$. For older samples concentrations of total amino acids vary but average about $150 \mathrm{nmol} / \mathrm{g}$. The decreasing concentrations with increasing depth and time of seven individual protein amino acids are shown in Figure 1. 

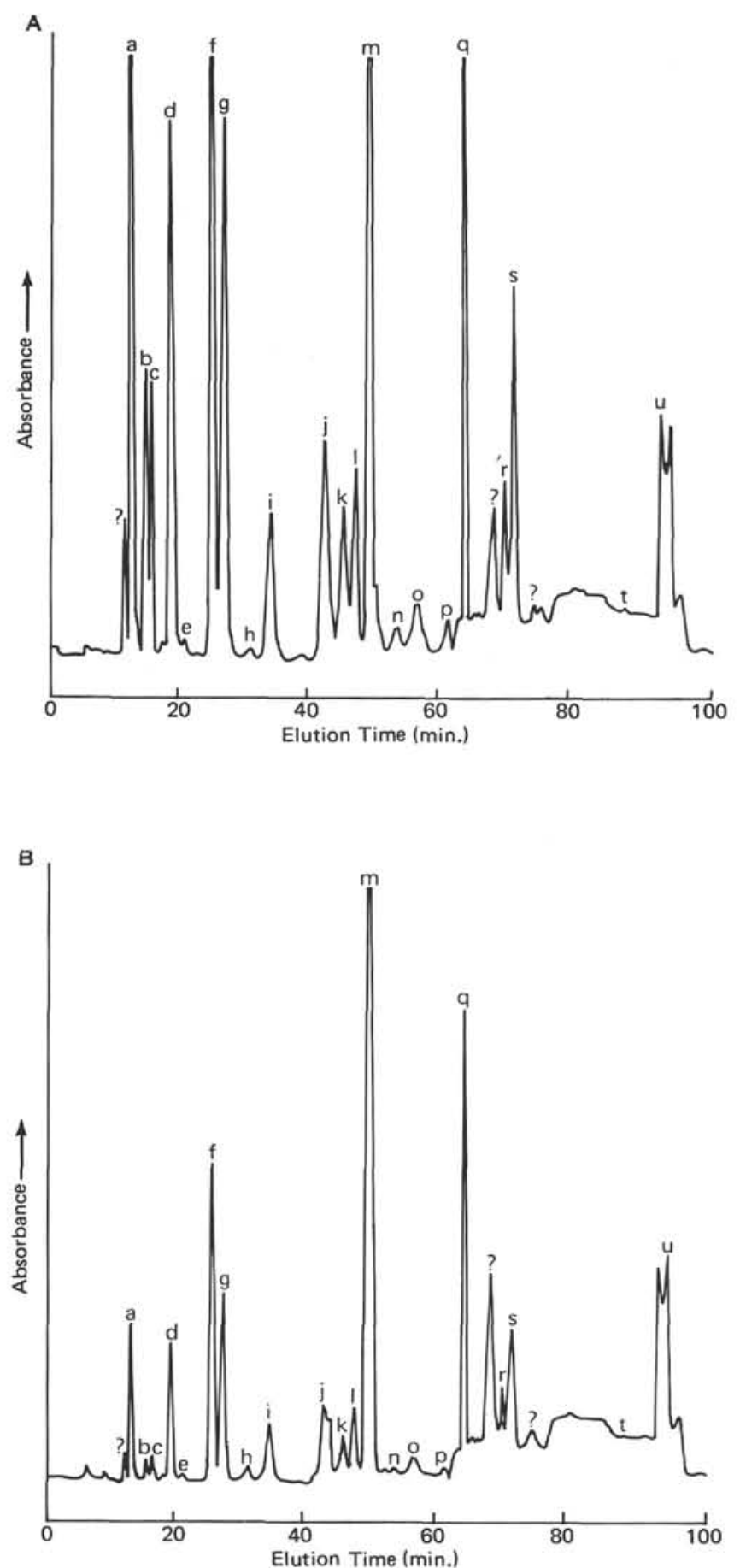

Figure 2. A. Ion exchange chromatogram of amino acids in the acid hydrolysate of Section 502B-2-2. The chromatogram shows the relative absorbance at $570 \mathrm{~nm}$ wavelength and elution time of ninhydrin-positive amino acids. (Identifications are: a, aspartic acid; b, threonine; c, serine; d, glutamic acid; e, proline; f, glycine; $\mathrm{g}$, alanine; h, $\alpha$-aminobutyric acid?; i, valine; j, composite peak of methionine, alloisoleucine and unknown; $\mathrm{k}$, isoleucine; 1 , leucine; $m$, norleucine (internal standard); $n$, tyrosine; $o$, phenylalanine; $p$, $\beta$-alanine; $\mathrm{q}, \boldsymbol{\gamma}$-aminobutyric acid; $\mathrm{r}$, histidine; s, ammonia + lysine; t, arginine; $\mathrm{u}, \mathrm{NaOH}$ regeneration.) $\mathrm{B}$. Ion exchange chromatogram of amino acids in the acid hydrolysate of Section $502 \mathrm{C}-15-2$. Identifications given above.
Table 1. Concentrations in nanomoles/gram and $\mathrm{D} / \mathrm{L}$ ratios of amino acids in sediment from DSDP Site 502.

\begin{tabular}{|c|c|c|c|c|c|c|c|c|}
\hline \multirow{4}{*}{$\begin{array}{l}\text { Hole } \\
\text { Core-Section } \\
\text { Sub-bottom Depth (m) } \\
\text { Age (m.y.) }\end{array}$} & \multicolumn{3}{|c|}{$502 \mathrm{~B}$} & \multicolumn{5}{|c|}{$502 \mathrm{C}$} \\
\hline & $2-2$ & $6-2$ & $18-2$ & $15-2$ & $21-1$ & $27-2$ & $29-1$ & $34-1$ \\
\hline & 4.3 & 22 & 75 & 96 & 121 & 143 & 214 & 225 \\
\hline & 0.3 & 1.0 & 2.9 & 3.6 & 4.4 & 5.0 & 7.3 & 7.7 \\
\hline $\begin{array}{l}\text { Aspartic acid } \\
\text { (D/L) }\end{array}$ & $\begin{array}{r}99 \\
(0.38)\end{array}$ & $\begin{array}{c}51 \\
(0.51)\end{array}$ & $\begin{array}{r}26 \\
(0.76)\end{array}$ & $\begin{array}{c}21 \\
(0.84)\end{array}$ & $\begin{array}{c}11 \\
(0.77)\end{array}$ & $\begin{array}{r}8 \\
(0.83)\end{array}$ & $\begin{array}{r}4 \\
(0.83)\end{array}$ & $\begin{array}{r}7^{7} \\
(0.90)\end{array}$ \\
\hline Threonine & 37 & 12 & 3 & 3 & 2 & 2 & $<1$ & $<1$ \\
\hline Serine & 34 & 13 & 4 & 3 & 3 & 3 & $<1$ & 1 \\
\hline $\begin{array}{l}\text { Glutamic acid } \\
(\mathrm{D} / \mathrm{L})\end{array}$ & $\begin{array}{c}82 \\
(0.21)\end{array}$ & $\begin{array}{c}42 \\
(0.33)\end{array}$ & $\begin{array}{c}26 \\
(0.52)\end{array}$ & $\begin{array}{c}23 \\
(0.64)\end{array}$ & $\begin{array}{c}13 \\
(0.63)\end{array}$ & $\begin{array}{c}11 \\
(0.61)\end{array}$ & $\begin{array}{c}6 \\
(0.64)\end{array}$ & $\begin{array}{r}9 \\
(0.74)\end{array}$ \\
\hline $\begin{array}{l}\text { Proline } \\
\text { (D/L) }\end{array}$ & $\begin{array}{r}56 \\
(0.26)\end{array}$ & $\begin{array}{r}27 \\
(0.42)\end{array}$ & $\begin{array}{r}18 \\
(0.61)\end{array}$ & $\begin{array}{c}20 \\
(0.69)\end{array}$ & $\begin{array}{c}11 \\
(0.53)\end{array}$ & $\begin{array}{l}\text { NR } \\
(0.49)\end{array}$ & $\begin{array}{l}\text { NR } \\
(0.68)\end{array}$ & $\begin{array}{c}\text { NR } \\
(0.65)\end{array}$ \\
\hline Glycine & 133 & 62 & 34 & 36 & 24 & 25 & 14 & 21 \\
\hline $\begin{array}{r}\text { Alanine } \\
(\mathrm{D} / \mathrm{L})\end{array}$ & $\begin{array}{c}121 \\
(0.29)\end{array}$ & $\begin{array}{r}66 \\
(0.39)\end{array}$ & $\begin{array}{r}39 \\
(0.71)\end{array}$ & $\begin{array}{c}48 \\
(0.79)\end{array}$ & $\begin{array}{c}23 \\
(0.71)\end{array}$ & $\begin{array}{r}20 \\
(0.69)\end{array}$ & $\begin{array}{c}12 \\
(0.80)\end{array}$ & $\begin{array}{r}20 \\
(0.77)\end{array}$ \\
\hline $\begin{array}{l}\text { Valine } \\
(\mathrm{D} / \mathrm{L})\end{array}$ & $\begin{array}{r}40 \\
(0.15)\end{array}$ & $\begin{array}{r}29 \\
(0.28)\end{array}$ & $\begin{array}{c}21 \\
(0.53)\end{array}$ & $\begin{array}{c}22 \\
(0.66)\end{array}$ & $\begin{array}{r}6 \\
(0.54)\end{array}$ & $\begin{array}{r}6 \\
(0.51)\end{array}$ & $\begin{array}{c}7 \\
(0.64)\end{array}$ & $\begin{array}{r}6 \\
\text { (NR) }\end{array}$ \\
\hline Isoleucine & 37 & 26 & 13 & 11 & 6 & 13 & 8 & 4 \\
\hline Leucine & 29 & 22 & 13 & 13 & 6 & 9 & 5 & 3 \\
\hline & $(0.16)$ & $(0.32)$ & $(0.49)$ & $(0.62)$ & $(0.51)$ & $(0,41)$ & $(0.73)$ & $(0.83)$ \\
\hline Tyrosine & 6 & 5 & 2 & 1 & $<1$ & $<1$ & $<1$ & $<1$ \\
\hline $\begin{array}{l}\text { Phenylalanine } \\
\text { (D/L) }\end{array}$ & $\begin{array}{r}17 \\
(0.25)\end{array}$ & $\begin{array}{c}11 \\
(0.38)\end{array}$ & $\begin{array}{c}7 \\
(0.47)\end{array}$ & $\begin{array}{c}6 \\
(0.69)\end{array}$ & $\begin{array}{r}3 \\
(0.65)\end{array}$ & $\begin{array}{c}3 \\
(0.58)\end{array}$ & $\begin{array}{l}<1 \\
(\mathrm{NR})\end{array}$ & $\begin{array}{r}2 \\
(0.72)\end{array}$ \\
\hline Histidine & 12 & 7 & 9 & 6 & 6 & 11 & 6 & 12 \\
\hline Arginine & $<1$ & $<1$ & $<1$ & $<1$ & $<1$ & (NR) & (NR) & (NR) \\
\hline$\gamma$-Aminobutyric acid & 144 & 53 & 83 & 89 & 61 & 52 & 23 & 45 \\
\hline$\beta$-Alanine & 178 & 59 & 49 & 50 & (NR) & 27 & (NR) & 11 \\
\hline Total & 1025 & 485 & 347 & 352 & 175 & 190 & 85 & 141 \\
\hline
\end{tabular}

Note: $N R=$ not recorded

These semi-logarithmic plots suggest that the processes causing a decrease in the concentrations of these amino acids approach first order. A first-order process has been suggested by Waples and Sloan (1980) to account for loss of nitrogen with increasing geologic age in a sediment core from the Shikoku Basin in the North Philippine Sea. Thus, the diagenesis of amino acids and of nitrogen may follow similar pathways. The trend of decreasing concentrations of amino acids with increasing geologic age is commonly observed (for a review, see Kvenvolden, 1975) and this decrease results from diagenetic processes that remove amino acids from the geologic record.

The nonprotein amino acids, $\gamma$-ABA and $\beta$-ALA, also decrease in concentration by about a factor of six from Holocene to late Miocene time. When compared with the total amino acid content, however, the percentages of these compounds increase from about 30 to $40 \%$ during the same time span. In their study of amino acids from a core of Pleistocene sediment in the western Atlantic Ocean, Aizenshtat et al. (1973) also noticed that the percentages of these two amino acids relative to total amino acids increased down the core from 13 to $70 \%$. These authors suggested that these two compounds were derived by decarboxylation of other amino acids such as aspartic and glutamic acids. Thus, the nonprotein amino acids probably are diagenetic alteration products from protein amino acids, but after they are formed, they undergo diagenetic processes that tend to decrease their absolute concentrations in the same manner that all amino acids are eventually reduced in concentration with increasing geologic time.

The dominant process causing an increase in enantiomeric $(D / L)$ ratios of amino acids in sediments is racemization, a reaction that is in part time-dependent. A first-order kinetic model, expressed by the following 

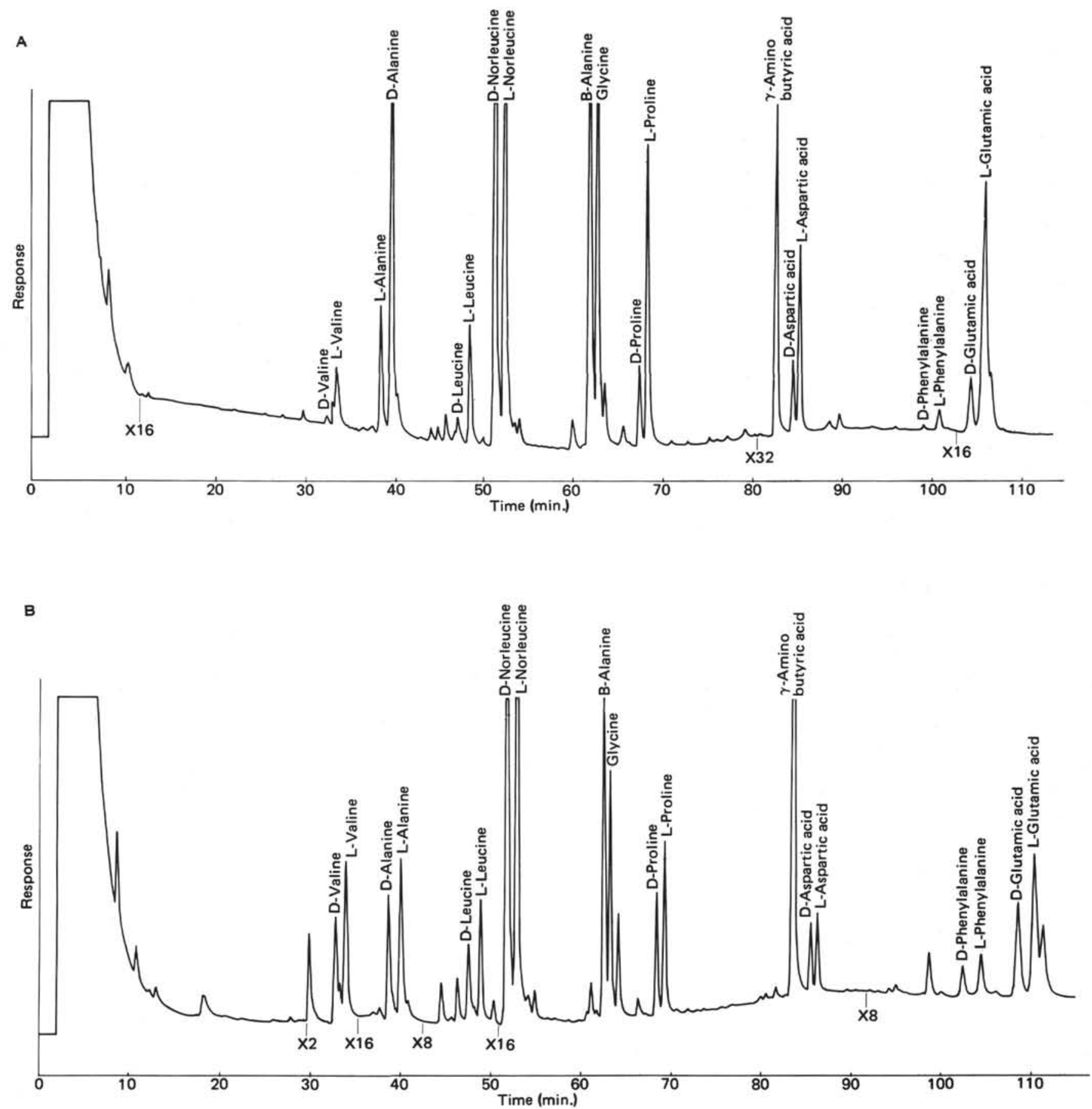

Figure 3. A. Gas chromatogram showing the separation and resolution of the diastereomeric derivatives of amino acids from the acid hydrolysate of Section 502B-2-2. Chromatographic column phase was UCON 75-H-90,000. B. Same as above except for Section 502C-15-2.

equation, derived by Bada and Schroeder (1972) has been used to interpret the data:

$$
\ln \left(\frac{1+D / L}{1-D / L}\right)=2 \mathrm{k} t+\text { constant, }
$$

where $D / L$ is a measure of the extent of racemization of an amino acid, $\mathrm{k}$ is the rate constant of racemization, and $t$ is time. The extent of racemization is determined by measuring the height of $D$ and $L$ peaks on gas chromatograms as illustrated in Figure 3. Table 1 shows the
$D / L$ ratios of seven of the amino acids from sediment samples at Site 502. In general, these ratios, expressed on the left side of equation 1, show approximately linear trends from 0.3 to about $3.6 \mathrm{Ma}$ (Fig. 1); that is, the racemization of the amino acids during this period appears to follow first-order kinetics. In older samples the $D / L$ ratios do not follow a predictable pattern, although the amino acids in the oldest samples (7.3 and $7.7 \mathrm{Ma}$ ) usually have the greatest extents of racemization (Fig. 1). These data suggest that only in the age range younger than about $3.6 \mathrm{~m}$.y. can amino acids 
from the acid hydrolysis of sediment at this site be used for age estimations. The order of the extents of racemization in the uppermost sample is aspartic acid > alanine $>$ proline $>$ phenylalanine $>$ glutamic acid $>$ leucine $>$ valine. This order, with a few exceptions, remains about the same for the four youngest samples; the order changes in samples older than $3.6 \mathrm{~m}$.y., although aspartic acid always has the greatest extent of racemization. Much of the randomness in $D / L$ ratios for the four oldest samples may be due to analytical variability resulting from the small concentrations of individual amino acids present in these samples.

Recently, Kvenvolden et al. (1980), following the lead of Bada et al. (1978b), have shown an excellent correlation between the natural logarithms of the ratio of concentrations of glycine and alanine versus $D / L$ ratios of alanine from clam shells of Saxidomus spanning about 0.5 m.y. When these same parameters are plotted for the samples from Site 502, a good correlation (correlation coefficient $=0.95$ ) exists for the four samples from the top of the core, but below about 100 meters data scatter (Fig. 4).

The period from 7.7 to $3.6 \mathrm{Ma}$ was characterized by sedimentation in which the average calcium carbonate content increased gradually from about 27 to about

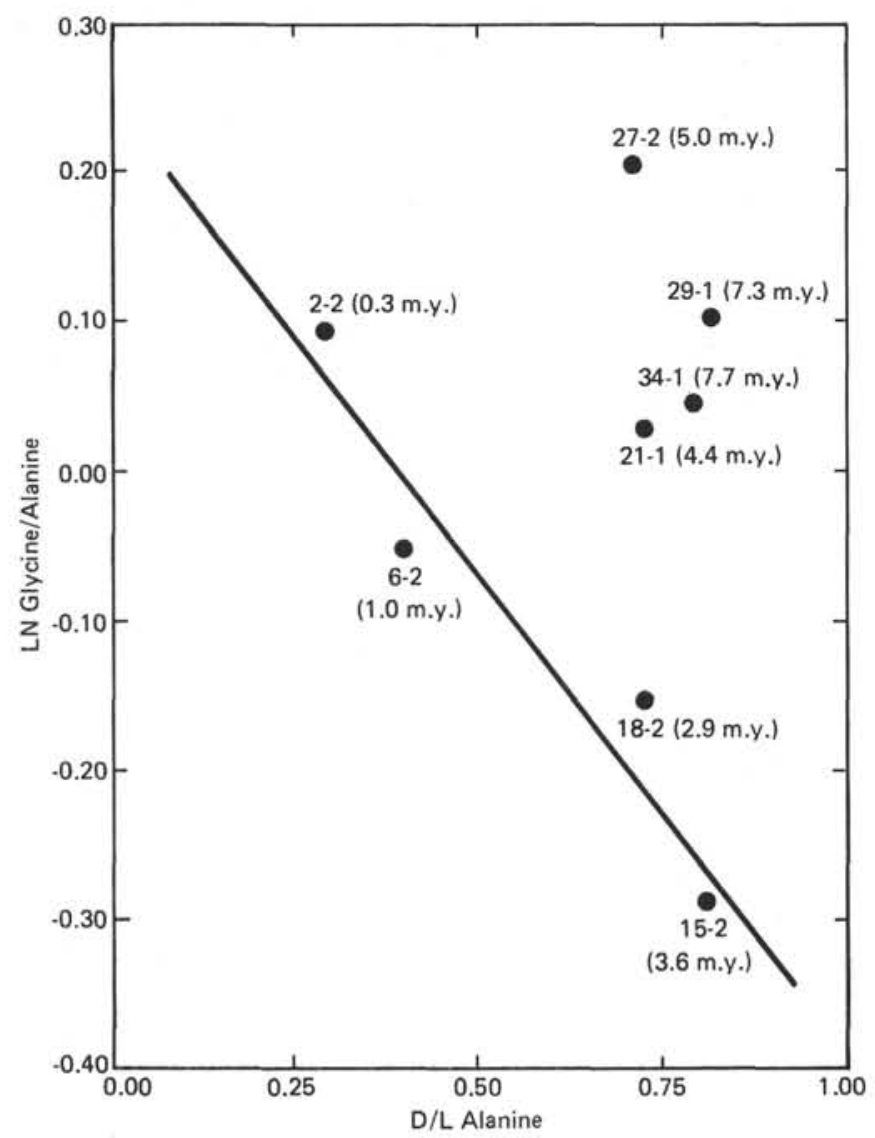

Figure 4. Graph of the natural logarithm of the ratio of concentrations of glycine to alanine versus the $\mathrm{D} / \mathrm{L}$ ratio of alanine for samples from Site 502, Leg 68. (The regression line fitted through Sections 502-2-2, 6-2, 18-2, and 15-2 has the equation $Y=0.63 \times$ +0.25 and a correlation coefficient of 0.95 .)
$49 \%$. Sediments younger than 3.6 m.y. have a uniform calcium carbonate content that averages in the range of 48 to $50 \%$. This uniformity may have provided conditions for the systematic diagenesis of amino acids, which is manifest in the regularity observed in the decreasing concentrations of amino acids with increasing age and the linearity of the trend of increasing $D / L$ ratios during this same period. Thus, data from calcium carbonate contents and abundances of amino acids and their enantiomeric ratios suggest that a change took place in the processes of sedimentation in this area of the Caribbean Sea about 3.6 Ma. Prell, Gardner, et al. (1980) correlate this time with the elevation of the site above the level of major near-bottom clay transport. These authors note that this is the period when the Isthmus of Panama emerged (3.2-3.6 Ma) according to the biostratigraphic evidence of Keigwin (1978). This emergence may have been responsible for an increase in the uniformity of sediment type and of contribution of organisms to the sediment record that followed. This uniformity may have created the conditions that led to the relatively systematic occurrence of amino acids and their enantiomers at this site during the last $3.6 \mathrm{~m} . \mathrm{y}$.

\section{SUMMARY}

Hydraulic piston coring at Site 502 on Leg 68 has provided a unique set of samples from which to evaluate the diagenesis of amino acids. Eight core samples from sub-bottom depths of 4.3 to 225 meters spanned an interval from 0.3 to $7.7 \mathrm{Ma}$ (middle Pleistocene to late Miocene). Concentrations of amino acids decreased and their $D / L$ ratios increased from sub-bottom depths of 4.3 to 96 meters, corresponding to an interval from 0.3 to $3.6 \mathrm{~m}$.y. Amino acids from deeper and older samples continued the same trend but with reduced regularity. During the last $3.6 \mathrm{~m} . \mathrm{y}$., the extent of racemization of amino acids follows first-order kinetics; therefore, during this period amino acids could be used for age estimations at this site. The change in trends of $D / L$ ratios of amino acids at about $3.6 \mathrm{Ma}$ corresponds to the time of the emergence of the Isthmus of Panama. This major geologic event altered the circulation in this area of the Caribbean Sea. The uniform conditions that resulted led to a uniformity of sedimentation during the last 3.6 m.y. This uniformity in sedimentation probably promoted, at least in part, the relatively systematic changes in amino acid concentrations and $D / L$ ratios during this period.

\section{ACKNOWLEDGMENTS}

We thank K. R. Lajoie and R. A. Schroeder for their critical reviews of this paper.

\section{REFERENCES}

Abelson, P. H., 1954. Organic constituents of fossils. Carnegie Inst. Washington Yearbk., 53:97-101.

1963. Geochemistry of amino acids. In Breger, I. A. (Ed.), Organic Geochemistry: New York (Macmillan), 431-455.

Aizenshtat, Z., Baedecker, M. J. and Kaplan, I. R., 1973. Distribution and diagenesis of organic compounds in JOIDES sediment from Gulf of Mexico and western Atlantic. Geochim. Cosmochim. Acta, 37:1881-1898. 
Bada, J. L., Luyendyk, B. P., and Maynard, J. B., 1970. Marine sediments: dating by the racemization of amino acids. Science, 170: 730-732.

Bada, J. L., and Man, E. H., 1973. Racemization of isoleucine in cores from Leg 15 Site 148. In Heezen, B. C., MacGregor, I. D., et al., Init. Repts. DSDP, 20: Washington (U.S. Govt. Printing Office), 947-951.

1980. Amino acid diagenesis in Deep Sea Drilling Project cores: kinetics and mechanisms of some reactions and their application in geochronology and in paleotemperature and heat flow determinations. Earth-Sci. Rev., 16:21-55.

Bada, J. L., Man, E. H., Katz, B. J., and Hsü, K. J., 1978a. Racemization of isoleucine in foraminifer tests from Leg $42 \mathrm{~A}$, Sites 372 and 376. In Hsü, K., Montadert, L., et al., Init. Repts. DSDP, 42, Pt. 1: Washington (U.S. Govt. Printing Office), 489-491.

Bada, J. L., Man, E. H., and Walker, A. C., 1977. Racemization of isoleucine in Leg 37, Sites 332 and 333 cores. In Aumento, F., Melson, W. G., et al., Init. Repts. DSDP, 37: Washington (U.S. Govt. Printing Office), 633-636.

Bada, J. L., and Schroeder, R. A., 1972. Racemization of isoleucine in calcareous marine sediments: kinetics and mechanisms. Earth Planet. Sci. Lett., 15:1-11,

Bada, J. L., Shou, M-V, Man, E. H., and Schroeder, R. A., 1978b. Decomposition of hydroxy amino acids in foraminiferal tests: kinetics, mechanisms and geochronological implications. Earth Planet, Sci. Lett., 41:67-76.

Degens, E. T., Emery, K. O., and Reuter, J. H., 1963. Organic materials in recent and ancient sediments-III: Biochemical compounds in San Diego Trough, California. Neues Jahrb. Geol. Palaeontol. Monatsh., 5:231-248.

Degens, E. T., Prasnowsky, A., Emery, K. O., and Pimenta, J., 1961. Organic materials in recent and ancient sediments-II: amino acids in marine sediments of Santa Barbara Basin, California. Neues Jahrb. Geol. Palaeontol. Monatsh., 8:413-426.

Erdman, J. G., Marlett, E. M., and Hanson, W. E., 1956. Survival of amino acid in marine sediments. Science, 124:1026.

Hare, P. E., 1969. Geochemistry of proteins, peptides, and amino acids. In Eglinton, G., and Murphy, M. T. J. (Eds.), Organic Geochemistry-Methods and Results: Berlin (Springer), pp. 438463.

1973. Amino acids, amino sugars, and ammonia in sediments from the Cariaco Trench. In Heezen, B. C., MacGregor, I. D., et al., Init. Repts. DSDP, 20: Washington (U.S. Govt. Printing Office), 941-942.

Hare, P. E., and Abelson, P. H., 1968. Racemization of amino acids in fossil shells. Year Book Carnegie Inst. Washington, 66:526-528.
Hare, P. E., and Mitterer, R. M., 1967. Nonprotein amino acids in fossil shells. Year Book Carnegie Inst. Washington, 65:362-364.

Keigwin, L. D., Jr., 1978. Pliocene closing of the Isthmus of Panama, based on biostratigraphic evidence from nearby Pacific Ocean and Caribbean Sea cores. Geology, 6:630-634.

Kvenvolden, K. A., 1975. Advances in the geochemistry of amino acids. Annu. Rev. Earth Planet. Sci., 3:183-212.

Kvenvolden, K. A., Blunt, D. J., and Clifton, H. E., 1979. Amino acid racemization in Quaternary shell deposits at Willapa Bay, Washington. Geochim. Cosmochim. Acta, 43:1505-1520.

Kvenvolden, K. A., Blunt, D. J., McMenamin, M. A., and Strahan, S. E., 1980. Geochemistry of amino acids in shells of the clam Saxidomus. In Douglas, A., and Maxwell, J. R. (Eds.), Advances in Organic Geochemistry 1979: London (Pergamon), pp. 321-332.

Kvenvolden, K. A., Peterson, E., and Pollock, G. E., 1972. Geochemistry of amino acid enantiomers: gas chromatography of their diastereomeric derivatives. In von Gaertner, H. W., and Wehner, H. (Eds.), Advances in Organic Geochemistry 1971: Braunschweig (Pergamon), pp. 387-401.

Mopper, K., Michaelis, W., Garrasi, C., and Degens, E. T., 1978. Sugars, amino acids, and hydrocarbons in Black Sea sediment from DSDP Leg 42B cores. In Ross, D. A., Neprochnov, Y. P., et al., Init. Repts. DSDP, 42, Pt. 2: Washington (U.S. Govt. Printing Office), 697-705.

Prell, W. L., Gardner, J. V., Adelseck, C., Blechschmidt, G., Fleet, A. J., Keigwin, L. D., Jr., Kent, D., Ledbetter, M. T., Mann, U., Mayer, L., Reidel, W. R., Sancetta, C., Spariosu, D., and Zimmerman, H. B., 1980. Hydraulic piston coring of late Neogene and Quaternary sections in the Caribbean and equatorial Pacific: Preliminary results of Deep Sea Drilling Project Leg 68. Geol. Soc. Am. Bull., Pt. I, 91:433-444.

Rittenburg, S. C., Emery, K. O., Hulsemann, J., Degens, E. T., Fay, R. C., Reuter, J. H., Grady, J. R., Richardson, S. H., and Bray, E. E., 1963. Biogeochemistry of sediments in experimental Mohole. J. Sediment. Petrol., 33:140-172.

Waples, D. W., and Sloan, J. R., 1980. Carbon and nitrogen diagenesis in deep sea sediments. Geochim. Cosmochim. Acta, 44: 1463-1470.

Wehmiller, J. F., and Hare, P. E., 1971. Racemization of amino acids in marine sediments. Science, 173:907-911.

, 1972. Amino acid content of some samples from Deep Sea Drilling Program. In Hays, J. D., et al., Init. Repts. DSDP, 9: Washington (U.S. Govt. Printing Office), 903-905. 